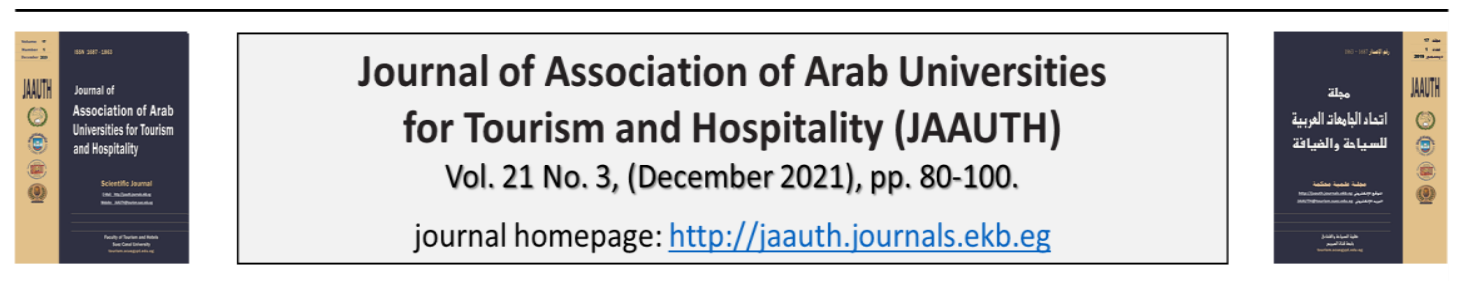

\title{
Mystery of Sunken Antiquities and its Effect in Promoting Tourism in Egypt: Case Study Alexandria Governorate-
}

\author{
Waleed Radwan Mahfouz Ibrahim Radwan \\ Department of Tourism Studies, Faculty of Tourism and Hotel Management, Helwan \\ University, Cairo, Egypt
}

\section{ARTICLE INFO \\ Keywords: \\ Sunken \\ Antiquities; \\ Alexandria; \\ Qaitbay; Abu Qir \\ Bay.}

\section{ABSTRACT}

Alexandria is characterized by many tourist attractions such as Qaitbay Castle, The library of Alexandria, the Sawari Column, the Burial chambers of Kom Al-Shoqafa, the Roman Amphitheater, the Temple of El-Ras El-soda, in addition to the sites of sunken antiquities...etc. that lead to the revitalization of the tourist movement in the city. In general, the beaches of Alexandria, particularly Abu Qir Bay and the Eastern Port area, are filled with treasures of sunken antiquities that have been sunk by natural phenomena for 15 centuries, particularly earthquakes that have thrown many of Alexandria's buildings, palaces and castles into the sea.

(JAAUTH) Sunken Antiquities in Alexandria are located in eight sites Vol. 21, No. 3, (December 2021), PP.80-100. which are the area of Qaitbay, the eastern port and outside the eastern port to Sidi Bishr Beach, the Area of Abu Qir Bay, the site of Nelson Island, and the location of the western port. The main data collection method involved in-depth, semistructured interviews with government officials and expert divers at main diving centers in Alexandria, and second phase involved three focus groups with tourism companies' managers. The paper recommends that the Ministry of Tourism and Antiquities in cooperation with The Center for Sunken Marine Antiquities in Alexandria should disseminate the archaeological awareness of marine antiquities and how to preserve them in schools, through the presentation of movies about sunken antiquities, and models simulations.

\section{Introduction}

Egypt incorporates numerous special fortunes everywhere on its urban communities like the Valley of the Nile with its Pharaonic landmarks and its cultural city of Cairo, the swimming and diving heaven of the Red Sea, the desert springs and open region of the encompassing deserts like Kharga, Dakhla, Farafra, Bahariya and Siwa, just as Alexandria with its chronicled, cultural and archeological legacy (Egypt Tours, 2019).

For a long time, Alexandria was the significant port city in the Eastern Mediterranean. It was established by Alexander the Great in 332 B.C, and expanded by the Ptolemies, who ruled until 30 B.C. The beaches of Alexandria, 
especially the Bay of Abu Qir and the Eastern Port area, include many sunken monuments that have been submerged because of the earthquakes and the risen of the sea level for about 2 meters since Roman times and so far. The most famous submerged buildings is the old Alexandria Lighthouse, which was one of the seven wonders of the ancient world and its traces and remains are found at a depth of 5 to 10 meters. The first evidence of an important sunken cultural heritage in the waters of Alexandria's eastern and western ports was discovered since the early 20th century, but serious archaeological excavations on the site did not begin until long afterwards (Shaaban, 2021).

The Sunken Cities in Abu Qir are viewed as the most alluring mark in Egypt, as the traveler can participate in a group diving trip organized by one of the city's authorized dive centers at Abu Qir Sea shore to see the submerged remnants of Heracleuim and Canopus, which date back to the time of the Ptolemaic rulers and the Greco-Roman epoch of the city, with some ancient Pharaonic relics as the remaining parts of the Temple of Isis, and the Palace of Cleopatra (Ministry of Tourism and Antiquities, 2019).

\section{Research Question}

The current research is designed to answer the following question: "To what extent the role of the Egyptian government is effective in promoting the Sunken Antiquities that were discovered in Alexandria as one of the main touristic attractions?"

\subsection{Aim and specific objectives}

The study aims to illustrate the historical importance of the Sunken Antiquities as one of the main touristic attractions that were discovered in Alexandria, and its effect in developing tourism in Egypt, and the role of the Egyptian government in promoting this segment.

In order to fulfill this aim, the following objectives were undertaken:

2.1.1 Illustrate the Touristic Attractions in Alexandria

2.1.2 Define Antiquities and Underwater Cultural Heritage

2.1.3 Explain the History of Sunken Antiquities

2.1.4 Identify the Main Site of Sunken Antiquities in Alexandria

2.1.5 Explore the Egyptian government's efforts for promoting Sunken Antiquities

\section{Review}

\subsection{Tourist Attractions in Alexandria}

Alexandria during ancient times was the capital of Egypt and named the "Bride of the Mediterranean" and" the Pearl of Egypt"(Memphis tours, 2021). It was built by Alexander the Great, so it was named after him. The city contains numerous antiquated Pharaonic places, religious landmarks, various recreational places, and numerous seashores known universally (Lonely Planet, 2021; Ammar, 2018). Perhaps the most appealing spots in Alexandria are as follows: Qaitbay Castle, which is the oldest Islamic landmark that was established by Sultan Ashraf SeifEldeen Qaitbay (Ministry of State for Administrative Development, 2004); the library of Alexandria is viewed as a guide of various cultures and arts around the globe (Elabbadi, 2021); the Sawari Column that traces all the way back to the Roman 
period in memory of ruler Diocletian (State Information Service, 2016); the Burial chambers of Kom Al-Shoqafa; the Roman Amphitheater traces all the way back to Roman time and is found in the Kom Al-Dakka region (Travel to Egypt, 2020); and the Temple of El-Ras El-soda was found in 1936, tracing all the way back to the Greco-Roman time (Egypt Tours, 2019). The main museums in Alexandria are the National Museum of Alexandria (Hawass, 2010); The Greco-Roman Museum; the Marine Biology Museum; the Museum of Fine Arts is; and the Royal Jewellery Museum (Ammar, 2018).

\subsection{Definitions of Antiquities and Underwater Cultural Heritage}

According to Cambridge Dictionary, (2021, p1) antiquity can be defined as:

"The distant past (a long time ago), especially before the sixth century, or an object that was created a very long time ago"

While Merriam Webster Dictionary, 2021, (p.1) defined antiquities as:

"Relics or monuments (such as coins, statues, or buildings) of ancient times, or Matters relating to the life or culture of ancient times"

The main difference between antique and antiquities that the word antique is an ancient French "meaning old" which is considered as an item sorted as being hundred years old at least, for example work of art or a piece of furniture that is so precious due to its value, age and quality, while antiquities return back to the ancient civilizations, i.e. thousands of years (Martinez, 2020).

According to the UNCLOS (The United Nations Convention on the Law of the Sea), which is an international treaty that was adopted and signed in 1982, and the 2001 UNESCO Convention, it is clear that Underwater Cultural Heritage is defined as:

"All traces of human existence having a cultural, historical or archaeological character which have been partially or totally under water, periodically or continuously, for at least 100 years such as: (1) sites, structures, buildings, artifacts and human remains, together with their archaeological and natural context; (2) vessels, aircraft, other vehicles or any part thereof, their cargo or other contents, together with their archaeological and natural context; and (3) objects of prehistoric character (Abd El-Maguid, 2012, p.22)".

\subsection{History of Sunken Antiquities in Egypt}

Historically, the real interest in the sunken antiquities in Egypt began in 1866, during the reign of Khedive Ismail, when Mahmoud Pasha El-Falaki drew up the first map of ancient Alexandria and its archaeological suburbs below the buildings of modern Alexandria. El-Falaki then identified the locations of the cities and ancient canals and the most important places of sunken antiquities in the Eastern Port based on the extensive excavations and archaeological work that was carried out. El-Falaki published this research in French language, and then followed by Gaston John Day, general director of the Egyptian Ports at that time between 1910 and 1914, when he was in charge of expansions in the Western Port of Alexandria; he discovered 
underwater installations similar to the docks west of the Pharos Peninsula (Badrawy, 2018).

Historians believe that the real beginning of the archaeological excavation of sunken treasures date back to 1933, during the reign of King Fouad I, by Prince Omar Tosson, a prince of the royal family who was resident in Alexandria. Tosson had many cultural and archaeological interests where he was known for his passion of antiquities and was a member of the Board of Directors of the Royal Antiquities Society of Alexandria at that time. During that time, an English pilot informed Tosson that he had seen traces in the water on a beach site of the sunken archaeological city of Menouthis off the coast of Abu Qir Bay, known as ancient Canopi. Prince Omar Tosson financed the search for these sunken antiquities and carried them out, and in cooperation with this English pilot who identified the ruins of the sunken city from air and were able to discover a marble head of Alexander the Great during 1934 (UNESDOC Digital Library, 2010).

During the 1960s, Kamel Abu Al-Sa'adat, a diving professional and archaeologist, drew up two maps for sunken antiquities, the first for sunken ruins of the Eastern Port, while the second was the Bay of Abu Qir. He also participated with the Navy in recovering some of his discoveries from El-Fanar site in 1962, where the French Navy, in cooperation with the Authority of Antiquities, studied the site of the sinking of Napoleon's fleet and the removal of some of its remnants. In 2000, a large collection of sunken antiquities was uncovered in the sunken city of Heracleuim by the French explorer Frank Goddio, as well as in the ancient east Canopus, which had been partially discovered by Prince Omar Tosson (Ammar, 2018).

In 1968, UNESCO, sent a mission to Alexandria to survey the consisting of the pioneer of archaeological diving Honor Frost and the geologist Vladimir Nesterov. They confirmed that the sunken ruins represented in two sites, mainly in some parts of the Lighthouse of Alexandria and the remains of the Palace of Alexander the Great, and it is of great historical and international importance. The excavation work was stopped after the war of 1967 for more than ten years until it was returned based on the report of Frost and Nesterov (Badrawy, 2018).

\subsection{Main Organizations and Centers responsible for Sunken Antiquities 3.4.1 UNESCO}

UNESCO has been concerned in safeguard and conserving the submerged legacy destinations in Alexandria for about 50 years, due to the studies that was done by the well-known archaeologist Kamel Abu Al-Sa'adat, the famous Egyptian expert in submerged relics in Alexandria and one of the explorers of these antiquities. After the 1967 war between Egypt and Israel, the coastal area of Alexandria were used for military zone only, and that make the exploration in the area unfeasible. In 1968, UNESCO sent a mission to Alexandria; consist of the archaeological diver Honor Frost and the geologist Vladimir Nesterov, where they visited the site and affirmed that the remnants representing a piece of the Pharos, some parts of Alexandria Lighthouse and the lost castle of Alexander and the Ptolemy. Activities in the area 
were stopped for about ten years; until it returned once more based on the report of Frost and Nesterov (Deyaa, 2019).

In the beginning of 1990s, the Ministry of Antiquities took actions to protect Alexandria's Qait Bay Citadel, from sea erosion. Approximately 200 cement blocks, were dropped on the sea floor along the site. However, unintentionally, the cement sea wall was being raised on the remnants of Alexandria's ancient lighthouse, the Pharos. In order to solve this problem, the Egyptian authorities in cooperation with UNESCO arranged a workshop in 1997 to protect Qait Bay Citadel without destroying the Pharos remains (UNESCO, 2017).

During the period between 1994 and 1998, a Franco- Egyptian team searched the sunken antiquities of the Pharos and other relics in Alexandria in order to setup a topographic map for the site, where the team discovered that the site occupies an area of 2.5 hectares and contain around 2500 pieces of archaeological stonework. Followed by this, another international team completed archaeological work on the site of the palace of Ptolemy (Deyaa, 2019).

Due to the heavy pollution in the water that facing the sunken antiquities in Alexandria, UNESCO sent a mission in 1998 in collaboration with Egyptian government to evaluate the situation. In 1998, another mission was sent by UNESCO to focus on conservation and development options for the underwater archaeological sites of Alexandria, where it was recommended to develop the Qait Bay Fort, and the Eastern port sites, as underwater museums. As a result, in 2006, an international workshop was held through UNESCO to study the opportunities in establishing an Underwater Museum (Deyaa, 2019 and UNESCO, 2017).

\subsubsection{Central Department of Sunken Antiquities in Egypt}

It is one of the departments related to the Egyptian Ministry of Tourism and Antiquities. Its nature is unique in working under the waters of seas, lakes, and Nile River, where the antiquities had been sunk due to the sinking of a ship or building, the factors of the erosion of seashores, or the fall of artifacts in the water (Ministry of Tourism and Antiquities, 2017).

This department was introduced in the Supreme Council of Antiquities after important discoveries in the Mediterranean waters of Alexandria in 1995 and 1996 when it revealed the remains of the Alexandria Lighthouse next to Qaitbay Castle and the Royal palace under the waters of the Eastern Port respectively. Thus, the administration was formed by a group of archaeologists, diving professionals who graduated from the faculties and departments of antiquities in all disciplines: Egyptian, Greek, Roman, Coptic and Islamic (Ministry of Tourism and Antiquities, 2017).

\subsubsection{The Center for Sunken Marine Antiquities in Alexandria}

It is considered as one of the most important centers that have become a global institution, and its role is not only to be a scientific center, but also to spread archaeological awareness by working to introduce the specialization of marine antiquities in Egypt as an underwater science. The center is the only specialized 
center in the field of sunken marine heritage of Africa and the Arab world (El-Masry, 2019).

The center was established in 2010, and aims to introduce the specialization of marine antiquities as a science in Egypt, because work in the field of sunken antiquities remained largely limited to foreign missions from the 1980s until the establishment of the center, where the role of Egyptians was only supervisory represented in the Ministry of Antiquities, despite the existence of a department of sunken antiquities specialized in underwater archaeological work but the academic scientific aspect was only available through foreign missions (El-Masry, 2019).

The most important marine archaeological projects carried out by the center, was the archaeological survey project in the area of Anchorage Bagush, which was launched in 2015, and resulted in the discovery of one of the most important archaeological ports on the northwest coast of Egypt dating back to the Roman era, and there is also the project of documenting ships sunken in the Red Sea, where the message of the center is limited only to the discovery and documentation of marine relics, without transferring the antiquities in accordance with the 2001 UNESCO Convention, which stipulates that sunken antiquities should be kept underwater (El-Saaty, 2020).

\subsection{Sunken Antiquities Expeditions in Alexandria}

\subsubsection{Mission of the European Institute for Underwater Archeology (IEASM)}

It is a Joint Mission between Egypt and France, working in excavations at the eastern port in Abu Qir under the head of the French Archeologist Franck Goddio, where the most important discoveries: the detection of the wreckage of three ships, the head of a royal statue of crystal, three gold coins, in addition to a metal boat for the idol Osiris, all dating back to the Roman era (Goddio, 2021). The mission as well identified at Abu Qir Bay six sites of sunken ships from the French fleet that participated in the Abu Qir naval battle. The survey and excavation work focused on the sinking sites of the flagship Orient, and the two frigates La Joure and La Sirius. Excavations have resulted in the discovery of many artifacts illustrating the nature of the arming of French forces. The Mission recovered a number of multi-purpose guns, light personnel weapons, some parts of the Orient flagship rudder, as well as printing characters that were not commonly used at the time. Many gold, silver and bronze coins of various categories were found from the Mediterranean countries that the French fleet passed through during its journey until it reached the coast of Egypt. The excavations also resulted in the discovery of the ruins of the city and the port, which were located at the mouth of the western branch of the Nile Delta known as the Canopi branch, which was named "Heracleuim". A Ptolemaic commemorative plaque containing the name of the city was also discovered, as well as at the bottom of the gulf, the wreckage of more than 60 ships and a large number of stone anchors was found (Goddio, 2021).

\subsubsection{Mission of the Hellenic Institute for Alexandrian Studies in Antiquity and the Middle Ages}

It is a Joint Mission between Egypt and Greece, working in surveying and excavations at El-Shatby in Alexandria under the head of Harry Zaltz, where the most 
important discoveries were about 400 architectural elements that was found, most likely to be the remains of the Temple of Isis, or the remains of the royal palace of Queen Cleopatra VII. The mission also found pottery fragments, most of them of the amphorae style, dating back to the Roman era (Ministry of Tourism and Antiquities, 2021a and El-Saaty, 2020).

\subsubsection{Alexandria Studies Center Mission}

It is a Joint Mission between Egypt and France, working in excavations at the site of Qaitbay Citadel in Alexandria under the head of Jean-Yves Embriere. The Mission started working since 1994 till now and discovered more than 3,000 archaeological pieces such as architectural columns, statues and columns, crowns made of pink granite, white marble, black marble with white veins, basalt, and quartzite. Thirty-six huge artifacts from these discoveries were transferred to the Kom El-Dikka area in order to display them in the corridor of the Roman Theater, including seven sphinxes and three obelisks. The mission also identified a site containing the remains of three sunken ships, likely belonging to the period between third century BC to the seventh century AD (Ministry of Tourism and Antiquities, 2021b).

\subsubsection{General Administration of Sunken Antiquities Mission}

It is an Egyptian Mission, working in surveying and excavations at the site of AlMaamoura Bay in Alexandria under the head of Central Department of Sunken Antiquities. The most important discoveries: Surveying and excavations resulted in the discovery of pottery fragments and some amphorae of different styles, which is likely to be related to sunken shipwrecks. The remains of a Roman ship sunken were found in the middle of the bay, which still show some archaeological elements at the bottom until now, and basins with straight ribs, carved in the rock, likely to have been used for raising fish. Parts of the sunken docks of a small port also appeared. Remains of an ancient quarry were also found to extract the yellow limestone that was used to build the ancient docks and basins in the bay dating back to Roman times (Ministry of Tourism and Antiquities, 2021b).

\subsection{The Main Site of Sunken Antiquities in Alexandria}

Alexandria submerged culture legacy traces all the way back to various periods, there are numerous cities submerged in the Alexandria coast.

\subsubsection{Abu Qir Bay}

It is an enormous bay on the Mediterranean Sea close to Alexandria, situated between the Rashid mouth of the Nile and the town of Abu Qir. It is distinguished by its rich sunken antiquities from the Pharaonic period to the modern time. The sunken cities in Abu Qir are Canopus, Menouthis, and Heracleuim, in addition to sunken fleet of Napoleon (Shaaban, 2021).

\subsubsection{Canopus}

It is an old Egyptian city, situated in the northeast of the harbor of Abu Qir. It is a region containing various remnants that was recognized in 1999. The Greeks called it Canopus, which was the site of a sanctuary to the Egyptian god Serapis that wad found close to a Christian landmark are greatly important. This site is around $150 \mathrm{M}$ long queue of remains, broken red stone columns, limestone building blocks and 
other archeological components, as well as different antiques from the Byzantine time including jewels and coins (Othman, 2020).

\subsubsection{Menouthis}

A British pilot caused Prince Omar Tosson to notice some old remnants lying submerged in Abu Qir, around $30 \mathrm{~km}$ from Qaitbay. In 1933, Tosson in cooperation with an expert diver discovered a marble head of Alexander. During the period from 1933-1942, Tosson and his associate undertook various missions that revealed other remaining parts, where they linked the town of Menouthis and its sanctuary with a submerged site found by reconsidering ancient sources (Affatato, 2012).

In 1997, The European Institute for Underwater Archaeology (IEASM) project started in Alexandria to find out the sunken antiquities of the city of Menouthis which vanished more than thousand years ago. The city was famous for their resources and way of life, as well as their temples dedicated to gods such as Serapis and Isis. In 1999, the discovery of Menouthis was announced, where many sunken antiquities were found such as broken columns and other architectural elements below the sea surface, many relics including granites and marble statues dates back from the $25^{\text {th }}$ Pharaonic dynasty to the Byzantine period; a collection of jewelry and gold coins dates back to Byzantine and early Islamic periods; in addition to the remains of one of the famous Isis temples were discovered (Othman, 2020).

\subsubsection{Thonis-Heracleuim}

These cities are stated as separated cities in the ancient Egyptian and Greek sources. However, excavation on the site proved that the two cities were, in fact, the same town. In 2001, the excavation started in the Heracleuim city in cooperation between the Egyptian team of UCH and the team of IEASM, where they discovered a ruin of the city, its port, ruins of sunken ships, and number of antiquities (Othman, 2020).

\subsubsection{The Fleet of Napoleon}

In 1998, the remaining parts of Napoleon's armada that soaked in 1798 due to the battle that occurred between the British Navy and the French Navy have been discovered by the European Institute for Underwater Archaeology, in addition to the discovery of the frigate La Serieuse. The institute has recovered as well gold and silver coins; ceramic, leather, wooden and metal relics from daily life, weapons (Shaaban, 2021)

\subsection{Egyptian Efforts for Promoting Sunken Antiquities \\ 3.7.1 Exhibitions Abroad}

In order to promote tourism in Egypt, numerous exhibitions included hundreds of sunken treasures in Egypt were organized at many countries. There was an exhibition held in 2008, which travels between the world's various cities, includes 489 rare artifacts, including pieces from sunken archaeological stores, as well as pieces from the Library of Alexandria Antiquities Museum, the Alexandria National Museum, the Greco-Roman Museum, and the Alexandria Restoration Laboratory. The exhibition's cities include Berlin, Bonn, in Germany, Paris in France, Madrid, in Spain Turin, in Italy, Yoko Hama, in Japan, Philadelphia and Los Angeles, in America (Shaaban, 2021). 
There was an exhibition held in France related to submerged fortunes in Egypt in the year 2015, under the title of "Osiris- the Secrets of Sunken Egypt". This exhibition was moved to England at the British Museum, and then finally, it was moved to Switzerland (Essam, 2020). There was also an exhibition held at Virginia museum in the United States of America, tracing all the way back to different authentic periods, for example, Pharaonic, Ptolemaic and Roman times too. This Exhibition included around 300 pieces that were found at numerous archeological sites in Alexandria for example, Qaitbay Castle, Maamoura Gulf, Eastern Port of Alexandria, Abu Qir Port, in addition to numerous submerged fortunes underneath the surface of the Nile in Aswan (Essam, 2020).

\subsubsection{Open Museum of Sunken Antiquities}

Temporarily, the first open museum of sunken antiquities in Alexandria was opened by the Ministry of Culture in the Area of the Roman Theater in the district of Kom Al-Dikka in Alexandria in 2010.This museum was built on a high-rise in the Area of the Roman Theater and occupies an area of 1200 square meters and displays about 39 artifacts recovered from the eastern port in the side located in front of the coast of the archaeological castle of Qaitbay in western Alexandria and includes part of the ancient Lighthouse of Alexandria and a statue of a woman 5.6 meters long in addition to an obelisk of the $19^{\text {th }}$ family engraved with the name of King City I, the first obelisk of sunken monuments to be displayed in Egypt and the world and weighs 18 tons and its base of sandstone as well as a collection of sphinx statues dating back to different eras (Badrawy, 2018). This open museum is considered as a part of the Roman Theater, where the tourists during their visit to the Roman Theater, they visit the open museum in the same program.

\subsubsection{The Idea of Establishing Underwater Museum for Sunken Antiquities}

In 1996, there was a proposal to establish a museum of sunken antiquities at the ancient Site of The Lighthouse of Alexandria to the north of Qaitbay Castle. The Egyptian Government was able to obtain the approval of the UNESCO to provide technical aid for the establishment of a museum of underwater antiquities in Alexandria. This proposal was adopted by the UNESCO Archaeological Site Management Conference in 1997 due to the erosion and obliteration of these under sea impacts due to pollution of seawater, where a report by the Ministry of Environment at the time revealed the contamination of the majority of coastal waters in Alexandria, and that the most polluted areas along the coast are those associated with untreated or partially treated sanitation sources such as Dakhla, Max, Eastern Port and Abu Qir. Most sites also feature high levels of nutritious salts, which result in abnormal growth of sea algae or the occurrence of the phenomenon of red tide, with adverse effects on the environment in general and the sunken effects of these sites in particular (Badrawy, 2018).

In 2009, a global architectural competition was held by the Supreme Council of Antiquities in Egypt under UNESCO supervision in order to establish the first underwater museum of sunken antiquities, involving four of the world's most famous and competent architectural designers, however, the construction of this museum is currently suspended after 25th January revolution in 2011 (Donahue,2015). 
The design of this museum came from four long buildings in the form of sails of Nile boats representing the four original directions and connected to each other and includes two parts, part above the surface of the water which is an open window for Panorama east port displaying the monuments that have already been recovered and a lower part underwater so that visitors can see the sunken monuments that have not yet been recovered either by diving to those who wish or by walking inside glass pipes (Badrawy, 2018).

\section{Methodological Approach}

This study is qualitative research, where a qualitative research methodology is selected to achieve a rich picture about the mystery of sunken antiquities in Alexandria and how to increase tourism in Egypt through promoting this segment.

Two main phases of fieldwork and data collection were conducted: The first phase: involves four in-depth, one-to-one, semi-structured interviews with government officials ( 2 experts at the Ministry of Tourism and Antiquities, and 2 experts at the Central Department of Sunken Antiquities), as well as five in-depth, one-to-one, semi-structured interviews with expert divers at main diving centers in Alexandria, mainly in Submarine Diving Center and Alexandria Dive to illustrate the discoveries of sunken antiquities in Alexandria.

The second phase: involves three focus groups with tourism companies' managers (type A) mainly in Cairo and Alexandria. Each group ranges from 4-5 participants. The focus groups provided a unique insight into the reactions of tourism companies' managers in promoting sunken antiquities in Egypt, and how to develop it. Focus groups was conducted to explore their views and opinions with regard to their participation in tourism development and to investigate the obstacles that face tourism companies in promoting sunken antiquities in Egypt. This was to develop an in-depth understanding of the main issues from a practical rather than a theoretical perspective.

\section{Research findings}

\subsection{Official Tourism Decision Makers "Personal Interviews"}

Based upon the in-depth interviews with some official tourism decision-makers, at the Ministry of Tourism and Antiquities, as well as at the Central Department of Sunken Antiquities in order to illustrate the discoveries of sunken antiquities in Alexandria; the divers working there; how to overcome any obstacles can face sunken antiquities; and the government strategy to develop and promote sunken antiquities in Egypt. The following issues were highlighted:

\subsubsection{Science of Sunken Antiquities}

According to all the experts at the Ministry of Tourism and Antiquities, as well as at the Central Department of Sunken Antiquities, it is clear that there is nothing called sunken antiquities science, but there is a marine archaeology science

"There is no so-called sunken antiquities science, as it is a technical and spatial term intended to practice archaeological work underwater only. But there is a marine archaeology science, but all discoveries 
are called archaeological discovery, and then to explore to what era the discovery belongs to, whether Greek, Pharaonic or Byzantine".

$$
\text { [Expert 3] }
$$

\subsubsection{Role of Egyptian Government in Discovering Sunken Antiquities}

Nowadays, the Egyptian government places a high priority for discovering sunken antiquities in Egypt through cooperation with foreign missions.

"At first, the Egyptian missions were only working, but over time, there is cooperation with many foreign missions to benefit from their experience in this field. In addition to the support of the Faculty of Arts at Alexandria University that assists with two missions, as well as there are agreements and protocols between Central Department of Sunken Antiquities and specialized archaeological institutes to work together to uncover undiscovered artifacts and archaeological sites".

$$
\text { [Expert 1] }
$$

\subsubsection{Sunken Antiquities Missions in Alexandria}

The main missions that operate in Alexandria are: the mission of the European Institute of Marine Archaeology in the Eastern Port and Abu Qir areas, the mission of the French Center for Alexandria Studies in Qaitbay Castle, the Greek mission in the east of the chain and even Sidi Bishr, working on the Southern coast of Lake Mariut, the Russian mission in the Western Port and does not currently operate, and the Italian mission on Nelson Island in Abu Qir

"The missions are expected to operate in the fall season from September to December, where in the spring season the missions were completely suspended due to the repercussions of the new Corona virus and that the sea atmosphere in the months 7 and 8 does not help in the work of missions."

[Expert 2]

"Missions take annual approvals for work and renew them every year"

[Expert 3]

\subsubsection{Training Divers in Excavations}

The Ministry of Tourism and Antiquities is the only side responsible for training divers.

"There are no private companies that train divers who work in excavators, but training and staff are through the ministry of Tourism and Antiquities. Participants in underwater excavators must have a diving license before joining missions, and there are ongoing training courses to develop the skills of divers."

[Expert 1] 


\subsubsection{Role of Egyptian Government in Promoting Sunken Antiquities in Egypt}

There are many ways to promote sunken antiquities in Egypt. One of the methods to promote submerged antiquities was through showing these antiquities in international exhibitions abroad, in addition to the idea of establishing a museum of underwater antiquities

"The exhibition "Treasures of Sunken Egypt" promoted Egypt significantly, where it began since 2006 to tour the world «Europe, France, Germany, Italy, Spain, Japan», and then returned again to Egypt, and in 2015 the exhibition came out to many countries such as: France, Germany, Switzerland and America".

[Expert 3]

"It is still the dream of the archaeologists and the Ministry of Tourism and Antiquities to establish a museum of underwater antiquities, but there are a number of things that must end first, the most important of which is the completion of open tourism projects and the opening of closed museums in the near future"

[Expert 4]

\subsubsection{Statistics for Numbers of Sunken Antiquities in Egypt}

All the experts illustrated that there is no clear statistics about the numbers of sunken antiquities in Egypt

"It is difficult to identify the number of sunken antiquities in Egypt. Many sites that have not been discovered yet, as it is possible to discover some archaeological sites by accident through excavations."

[Expert 1]

"The site of Qait Bay Castle contains more than 3,500 artifacts, belonging to a number of ancient historical times, a submerged ship deep under the sea, the ancient Lighthouse of Alexandria, as well as there are many other pieces in Abu Qir."

[Expert 4]

\subsubsection{Ways of Preserving Sunken Antiquities}

The sunken antiquities after being extracted from water, are transferred to certain stores specialized for that purpose, to protect it from theft factors.

"After all maintenance and restoration work is done to the discovered pieces, to be ready for museum display, while the discovered largescale monuments are placed in its original place to protect the cultural heritage in the water."

[Expert 1] 


\subsubsection{Indicators of Existing Sunken Antiquities}

The main indicators that point to the existence of sunken antiquities based on several things such as: old sources, fishermen's reports, and traditional research through diving survey

"The old sources and the writings indicating that the place has antiquities, in addition to relying on reports from fishermen about the presence of monuments in this place, as well as the traditional research carried out through diving survey, which is very difficult because of the water current, where devices is used to show the existence of buried artifacts in this place or not".

[Expert 2]

\subsubsection{Main Sites of Sunken Antiquities in Alexandria}

All the experts mentioned that there are eight sites where sunken antiquities were discovered

"There are eight sites of sunken antiquities in Alexandria, and they are located in the area of Qaitbay, the eastern port and outside the eastern port to Sidi Bishr Beach, the Area of Abu Qir Bay, the site of Nelson Island, and the location of the western port."

[Expert 4]

\subsubsection{Recent Discovered Sunken Antiquities in Alexandria}

There are many recent sunken antiquities that was discovered in Alexandria such as: Greek funerary area, wreckage battleship, and giant Ptolemaic queen statue

"The General Administration of Sunken Antiquities Mission succeeded in finding the remains of a Greek funerary area dating back to the beginning of the fourth century $B C$, at the entrance to the northeastern canal of the city, which shows the presence of Greek merchants who lived in that city and controlled the entrance of Egypt at the mouth of the Canopi branch of the Nile. They were allowed to settle during the late Pharaonic period and set up their funeral temples near the main temple of Amon, but due to natural disasters the area was destroyed, and its archaeological remains were discovered mixed with the Temple of Amon, stable, and in excellent condition, in the deep canal. These monuments bear witness to the richness of the temples of the city, which is now located below the Mediterranean Sea, seven kilometers from the beach of Abu Qir.

[Expert 1]

"A wreckage battleship that belongs to the Ptolemaic period was discovered, where this ship is long with a length of more than 25 meters, and its body was built according to the classical model, yet it contains the features of the old Egyptian style, and therefore, it is a mixed type of construction. This ship has flat spots and a flat keel, a 
very useful model for navigation in the Nile and within the Delta, and has paddles with a large sail as evidenced by the shape of the largedimensional mast. As some typical ship building features in ancient Egypt suggest, as well as evidence of timber reuse, the ship was built in Egypt".

[Expert 3]

"A giant Ptolemaic queen statue, the rose granite statue, was found from the $4^{\text {th }}$ to $3^{\text {rd }}$ century $B C$, aged 2400 years, and was unveiled in 2000, broken and divided into five parts, and then recovered, transported and preserved in the stores of the Central Administration of Sunken Antiquities".

[Expert 4]

\subsection{Divers at Diving Centers in Alexandria "Personal Interviews"}

Based upon the in-depth interviews with divers at the main diving centers in Alexandria, which are Submarine Diving Center, and Alexandria Dive, the following issues were highlighted:

\subsubsection{Diving in Alexandria}

According to all the divers at the main diving centers in Alexandria, it is clear that the hobby of diving is not very widespread in Alexandria

"Citizens are only interested in diving in the Red Sea to see the coral reefs, not to know the sunken antiquities in Alexandria".

[Diver1]

\subsubsection{The Main Sites for Diving in the Sunken Antiquities Areas}

There are two open museums underwater, where tourists are allowed to dive there, namely the Qaitbay Castle Museum and the Eastern Port Museum.

"The sunken antiquities have two open underwater museums, and tourist groups are allowed to dive to enjoy them, namely the Qaitbay Castle Museum, which houses about 3,000 sunken artifacts of various ages, and the Eastern Port Museum and houses many fixed pieces such as docks, port docks and a World War II aircraft."

[Diver 2]

\subsubsection{Tourist's Nationalities visiting Sunken Antiquities}

According to all the divers at the main diving centers in Alexandria, they stated that the main nationalities visiting Sunken Antiquities are from France, German, Italy, Ukraine and United Kingdom.

\subsubsection{Training Divers in Excavations of Sunken Antiquities}

The Ministry of Tourism and Antiquities is the only party responsible for training divers, where divers in underwater excavations must have a diving license before joining foreign missions, in addition to continuous training courses in order to develop the skills of divers. 


\subsubsection{Main Problems Facing Sunken Antiquities in Alexandria}

The main problem that affects negatively the sunken antiquities is the pollution of the industrial drainage.

"The most important problem that affects negatively the sunken antiquities is the industrial drainage that comes from the factories that are dumped in Abu Qir Bay in Tabia area, where the drainage that comes from Rashid branch, is agricultural drainage, bordering the Bay of Abu Qir from the east side and the sunken monuments on the west side, and therefore has no effect"

\section{[Diver 1]}

Industrial drainage affects sunken antiquities and causes them to blacken, therefore the sunken antiquities after transferring them from water, they are placed in salt-free water to get rid of salts gradually and are transported to the stores at the Department of Sunken Antiquities.

[Diver 3]

"The sunken antiquities most affected by environmental pollution are made up of sand materials, where the change in sea level and the phenomenon of sculpture and sedimentation affects the archaeological site".

\section{[Diver 4]}

"There are approximately 20 factories that threw their industrial drainage on Abu Qir Bay, where, many records have been edited for violations of Environment Law No. 4 of 1994 and caused environmental pollution in the Gulf".

[Diver 5]

\subsection{Tourism Companies Managers - Type A "Focus Groups"}

Based upon three focus groups with tourism companies' managers (type A) mainly in Cairo and Alexandria, where each group ranges from 4-5 participants, the following issues were highlighted:

5.3.1 There are about $60 \%-70 \%$ of Egypt's archaeological tourist places not visited by tourists, and is not located on the map of Egypt tourism, as almost all the touristic programs presented to tourists are invariable, and miss any attempt for diversification, which led to the presence of places in the under-secrecy such as sunken antiquities in Alexandria, and not putting them within tourist programs, besides the famous classical places such as Pyramids, Egyptian Museum, Mohammed Ali Castle in addition to Luxor and Aswan.

5.3.2 Non-exploitation of the monuments of ancient Alexandria soaked in water due to lack of marketing and publicity to these antiquities, despite the presence of 
statues and columns of large sizes that will not allow them to be removed from the water, which sank as a result of natural factors and erosion of the beaches.

5.3.3 The majority of Tourism companies' managers stated that the main country of the tourist used to visit sunken antiquities in Alexandria is France, followed by German, Italy, and United Kingdom.

5.3.4 The number of tourists used to visit sunken antiquities in Alexandria before 2011 revolution were much more than nowadays due to several circumstances, from which the instability of the country after 2011 revolution, and currently due to the spreading of Covid-19 all over the world which affect the arrival of tourists to the sunken antiquities, in addition to the lack of marketing and promotion to these sites.

5.3.5 The Egyptian government represented in the Ministry of Tourism and Antiquities should focus on the sites of sunken antiquities in Alexandria and put it on the tourism map which will lead to increase the number of tourists visiting these relics.

\section{Results}

Egypt is a unique case in marine antiquities, as there is no country with a quantity or area of archaeological sites in Egypt, which is about 5,000 kilometers along the white and red coasts, and Alexandria is a more unique case because the archaeological sites have a large area, such as: the area of Abu Qir, Qaitbay, and the Eastern Port and its successive monuments, from which the maritime history of Egypt can be read.

The current study evaluated the mystery of sunken antiquities in promoting tourism in Egypt, especially in Alexandria. The main data collection method involved four indepth, one-to-one, semi-structured interviews with government officials, as well as five in-depth, one-to-one, semi-structured interviews with expert divers at main diving centers in Alexandria; second phase involved three focus groups with tourism companies' managers (type A) mainly in Cairo and Alexandria. This leads to the following results:

1. Historically, the real interest in the sunken antiquities in Egypt began in 1866, during the reign of Khedive Ismail, while Historians believe that the real beginning of the archaeological excavation of sunken treasures in Alexandria date back to 1933, during the reign of King Fouad I, by Prince Omar Tosson.

2. The site of "Abu Qir" is considered one of the most important sites that sunken antiquities were discovered there, as it was the main entrance to Ancient Egypt, and where all ships gathered before entering Egypt and therefore the movement of trade as a whole was passing through it, in addition to that it played a very important role for trade before the construction of the city of Alexandria.

3. The sunken cities in Abu Qir are Canopus, Menouthis, and Heracleuim, in addition to sunken fleet of Napoleon; therefore, the Abu Qir Bay is a witness to the history of the region in many periods, as inside Abu Qir Bay in the port of Heracleuim there were over 73 old boats submerged there. 
4. Sunken Antiquities in Alexandria exist whether in the "Eastern Port" and the remains of the old royal neighborhood; antiquities of fixed remains such as "buildings, and remnants of floors", in addition to some monuments such as "columns, sphinx statues, old sunken boats", as well as in the "Castle of Qaitbay", where there are the remains of the old Lighthouse of Alexandria, which was restored more than once until it collapsed completely, and is now located in front of the castle of Qaitbay in the water.

5. Most of the sunken antiquities recovered are a collection of pieces discovered by the Egyptian-French mission headed by the archaeologist Frank Goddio, which is displayed through an international exhibition touring some European, American and Asian cities that reflect the thought, art, civilization, of the ancient Egyptian in a number of European cities so that the world can see an important mythical and historical part of ancient Egypt's civilization.

6. The main organizations and centers responsible for protecting and conserving the submerged legacy destinations in Alexandria are UNESCO, Central Department of Sunken Antiquities in Egypt, and the Center for Sunken Marine Antiquities in Alexandria.

7. The main missions that operate in Alexandria are: the mission of the European Institute of Marine Archaeology in the Eastern Port and Abu Qir areas, Mission of the Hellenic Institute for Alexandrian Studies in Antiquity and the middle Ages, it is a Greek mission in the east of the chain and even Sidi Bishr, working on the Southern coast of Lake Mariut, Alexandria Studies Center Mission in Qaitbay Castle, General Administration of Sunken Antiquities Mission, the Russian mission in the Western Port and does not currently operate, and the Italian mission on Nelson Island in Abu Qir

8. The results from the in-depth interviews with government officials at the Ministry of Tourism and Antiquities, and the Central Department of Sunken Antiquities clarify that the Egyptian government places a high priority for discovering sunken antiquities in Egypt through cooperation with foreign missions, where the Ministry of Tourism and Antiquities is the only side responsible for training divers.

9. There are many ways to promote sunken antiquities in Egypt. One of the methods to promote submerged antiquities was through showing these antiquities in international exhibitions abroad, in addition to the idea of establishing a museum of underwater antiquities

10. The main indicators that point to the existence of sunken antiquities based on several things such as: old sources, fishermen's reports, and traditional research through diving survey, where the sunken antiquities after being extracted from water, are transferred to certain stores specialized for that purpose, to protect it from theft factors.

11. There are about $60 \%-70 \%$ of Egypt's archaeological tourist places not visited by tourists, and is not located on the map of Egypt tourism, as almost all the 
touristic programs presented to tourists are fixed, and miss any attempt for diversification, which led to the presence of places in the under-secrecy such as sunken antiquities in Alexandria

\section{Recommendations}

1. The Ministry of Tourism and Antiquities should make a clear marketing plan to promote Sunken Antiquities in Egypt, especially in Alexandria, as this segment can increase the national income of Egypt.

2. The Ministry of Tourism and Antiquities in cooperation with The Center for Sunken Marine Antiquities in Alexandria should disseminate the archaeological awareness and the importance of marine antiquities and how to preserve them for students in schools, through the presentation of movies about sunken antiquities, models simulations and diving tools.

3. The Ministry of Tourism and Antiquities should activate the Antiquities Act, through declaring the Egyptian beaches that have sunken antiquities as Natural reserves, especially since the recovery of sunken monuments is expensive, as well as the lack of appropriate places, which is considered one of the most important problems faced by this rare world heritage, which is not like any other country in the world.

4. The Ministry of Tourism and Antiquities in cooperation with other stakeholders should start immediately in implementing the idea of establishing the underwater museum which is expected to become a new beacon for the city of Alexandria to be a journey through time to discover the secrets of the ancient city sunken underwater, which includes the Temple of Amon, the old port and the Palace built by Mark Antonio for Queen Cleopatra.

5. The Ministry of Tourism and Antiquities, in cooperation with UNESCO, should prepare a short documentary to be presented in the various media about how to preserve the underwater cultural heritage in Alexandria, where attention focuses on the UNESCO Convention on the Protection of Underwater Cultural Heritage and highlights the importance of preserving underwater cultural property.

6. The Ministry of Tourism and Antiquities should set up a cultural center on Abu Qir site in Alexandria, in order to serve the local community as well as the tourists and get income from it, which will help the center to continue introducing its services and achieve its goals.

\section{References}

- Abd-El-Maguid. M., (2012). Underwater Archaeology in Egypt and the Protection of its Underwater Cultural Heritage. Journal of Maritime Archeology, Vol. 7:193-207.

- Affatato, A., (2012). Underwater Cultural Heritage: Sunken cities, A.Y. 2011/2012,

- Ammar, S., (2018). Alexandria Egypt- Greater Than a Tourist, CZYK Publishing LLC, ISBN 9781980419563, Cairo-Egypt, pp.21-34 
- Badrawy, T., (2018). Museum of Sunken Antiquities, Abou Al-Hool Newspaper, Cairo, Egypt, First Egyptian Tourist Newspaper, June 2018, PP 12-14.

- Cambridge Dictionary, (2021). Meaning of Antiquity, [on line], available from: https://dictionary.cambridge.org/dictionary/english/antiquity, accessed on [25 July 2021].

- Deyaa, N., (2019).UNESCO's workshop tackles underwater cultural heritage for the first time in Egypt, [online], available from:https://dailyfeed.dailynews egypt.com/ 2019/11/11/ unescos-workshop-tackles-underwater-cultural-heritagefor-the-first-time-in-egypt/, accessed on [24 August 2021].

- Donahue, M., (2015). An Underwater Museum in Egypt Could Bring Thousands of Sunken Relics into View, [online], available from https://www.smithsonianmag. com/ innovation/underwater-museum-egypt-couldbring-thousands-sunken-relics-into-view-180957645/ , accessed on [22 May 2020].

- Egypt Tours, (2019).Temple of the Black Head in Alexandria [online], available from: $\quad$ https://enjoyegypttours.com/temple-of-the-black-head-in-alexandria/, accessed on [4 April 2021].

- Elabbadi, M., (2021).Library of Alexandria, [online], available from: https:// www.britannica.com/topic/Library-of-Alexandria, accessed on [5 June 2021].

- El-Masry, H., (2019). Exploratory Mission to Search for Sunken relics, ElAhram Newspaper, Cairo, Egypt, p.6

- El-Saaty, H., (2020). Foreign Missions for Sunken Antiquities, [online], available from:https://www.shorouknews.com/news/view.aspx?cdate=06072020\&id=bf40de d0-b61e-4a68-99b9-2daff1d9cb14, accessed on [ 25 August 2021].

- Essam, A., (2020). Egypt's sunken treasures exhibition, [online], available from: https://www.egypttoday.com/Article/4/89241/Egypt\%E2\%80\%99s-sunkentreasures -exhibition-was-inaugurated-at-Virginia-Museum-of, accessed on [15 June 2021].

- Goddio, F., (2021). Napoleon Bonaparte's Fleet, [on line], available from: https://www.franckgoddio.org/projects/others/napoleon-bonapartes-fleet. html, accessed on [25 July 2021].

- Hawass, Z., (2010). Alexandria National Museum, Second Edition, Publisher American University in Cairo Press, ISBN -10:9773055582, Cairo-Egypt, pp.3031.

- Lonely Planet, (2021). Alexandria, [online], available from: https://www. lonelyplanet.com/egypt/mediterranean-coast/alexandria/attractions, accessed on [19 July, 2021].

- Martinez, J., (2020). Learning the Difference: Retro, Vintage, Antique, and Antiquity Explained, [online], available from: https://www.thecollector. com/ retro-vintage-antique-antiquity-differences-explained/, Accessed on [28 July 2021]. 
- Memphis Tours, (2021). The Great Library of Alexandria, [online], available from: $\quad$ https://www.memphistours.co.uk/Egypt/Egypt-Travel-Guide/AlexandriaAttractions /wiki/ Alexandria-New-Library-Egypt, accessed on [7 May 2021].

- Merriam-Webster, (2021). Definition of Antiquities, [online], available from: https://www.merriam-webster.com/dictionary/antiquity, accessed on [20 July 2021].

- Ministry of State for Administrative Development, (2004). Qaitbay Fort Alexandria, [online], available from: http://www.alexandria.gov.eg/Alex/english/ qaitbay\% 20fort.html, accessed on [15 May 2021].

- Ministry of Tourism and Antiquities, (2021a)., Hellenic Expedition, [on line], available from: http://www.antiquities.gov.eg/DefaultAr/expeditions/Pages/ expeditiondetails.aspx? Expedition Code $=47$, accessed on [3 August, 2021].

- Ministry of Tourism and Antiquities, (2021b). Alexandria Studies Center Mission, [on line], available from: http://www.antiquities.gov.eg/DefaultAr/ expeditions /Pages/ expeditiondetails.aspx? Expedition Code $=47$, accessed on [7 August, 2021].

- Ministry of Tourism and Antiquities, (2019). Sunken Monuments - Abu Qir Bay, [online], available from: https://egymonuments.gov.eg/sunken-monuments/abuqir-bay/, accessed on [22 May.2021].

- Ministry of Tourism and Antiquities, (2017). Sunken Antiquities, [on line], available from: http://www.antiquities.gov.eg/DefaultAr/UnderwaterArchaeology /Pages/default.aspx , accessed on [27 August, 2021].

- Othman, S., (2020). Sunken Cities: Underwater Culture Heritage of Alexandria at Abukir Bay, International Journal of Multi Disciplinary studies in Architecture and Cultural Heritage, ISSN: 2735-4415, Volume 3, Issue 2, pp 95-105

- Shaaban, D., (2021). City of Alexandria, Full of Archaeological Sites, El-Shrouk Newspaper, Cairo, Egypt, p 6.

- State Information Service, (2016). Pompey's Pillar, [online], available from: https://www.sis.gov.eg/Story/101115/Pompey's-Pillar-\%E2\%80\%83?lang=en-us, accessed on [8 April, 2021].

- Travel to Egypt, (2020). Catacombs of Kom El Shoqafa, [online], available from: https://www.traveltoegypt.net/discover-egypt/alexandria attractions/catacombs-ofkom-el-shoqafa, accessed on [29 June 2021].

- UNESCO, (2017). The Alexandria Underwater Museum Project, [online], available from: http:// www.unesco.org/new/en/culture/themes/underwatercultural-heritage/ about-the-heritage/ under water-museums/alexandria-museumproject/, accessed on [15 August 2021]

- UNESDOC Digital Library, (2010). National Report on Underwater Cultural Heritage Report made in the UNESCO Regional Meeting in Istanbul $25-27$ October, 2010, [online], available from: https://unesdoc.unesco.org/ark :/ 48223 / pf0000189962, accessed on [11May 2021]. 


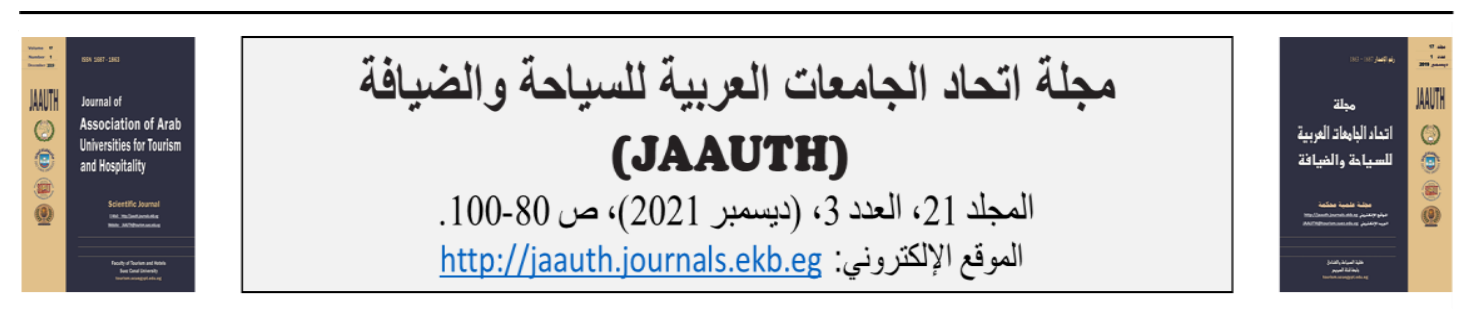

لغز الآثار الغارقة وتأثيرها في الترويج للسياحة في مصر : دراسة حالة محافظة الإسكندرية

$$
\text { وليا رضوان محفوظ إبراهيم رضوان }
$$

قسم الدر اسات السياحية، كليه السياحة و الفنادق، جامعه حلو ملو انه، القاهرة، مصر

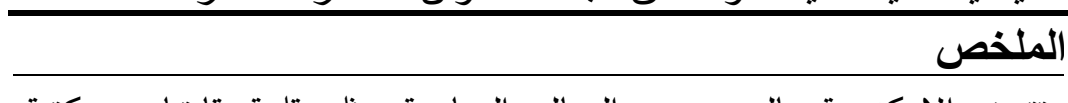

تتميز الإسكندرية بالعديد من المعالم السياحية مثل قلعة قايتباي، مكتبة

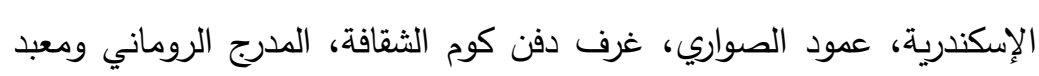

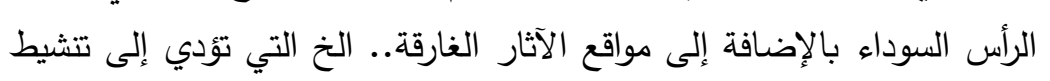
معلومات المقالة الآثار الغارقة؛ الإسكندرية؛

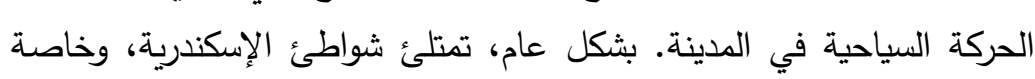
خليج أبو قير ومنطقة الميناء الثرقي، بكنوز الآثار الغارقة التي أغرقتها الظواهر الطبيعية لمدة 15 قرنا، خاصة الزلازل التي ألقت بالعديد من مباني لأني الإسكندرية وقصورها وقلاعها في البحر. تقع الآثار الغارقة بالإسكندرية في داني ثمانية مواقع هي منطقة قايتباي والميناء الشرقي وخارج الميناء الشرقي إلى قايتباى؛ خليج أبو قير · ت الانت

شاطئ سيدي بشر ومنطقة خليج أبو قير وموقع جزيرة نيلسون وموقع الميناء الغربي. لقد انقسم الدراسة الميدانية التي تم القيام بها إلى مرحلتين أساسيتين: المرحلة الأولى وتشمل إجراء مقابلات شخصية متعمقة وشبه منظمة مع في فئم مسؤولين حكوميين فى وزاره السياحه والاثار وكذلك مسئولين فى الاداره المركزيه للاثار الغارقه، كذلك تم عمل مقابلات شخصيه مع خبراء الغوص في مراكز

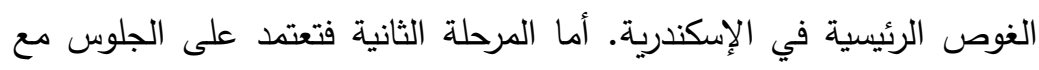
مجموعات محددة ومستهدفه من مديري شركات السياحة (فئة ا) في القاهرة

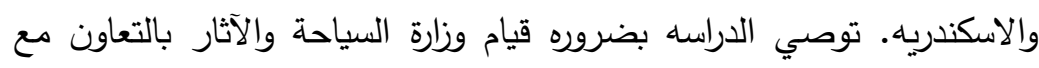
مركز الآثار البحرية الغارقة بالإسكندرية بنشر الوعي الأثري للآثار البحرية

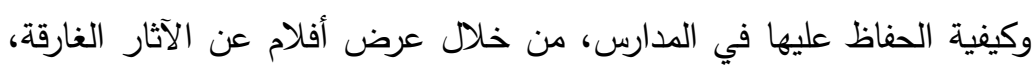
ونماذج محاكاة لها. 